\title{
Kemampuan Good Corporate Governance Memoderasi Pengaruh Nilai Perusahaan pada Praktik Perataan Laba
}

\author{
Ni Made Dwi Permanasari ${ }^{1}$ \\ I Ketut Suryanawa ${ }^{2}$
}

\author{
${ }^{1}$ Fakultas Ekonomi dan Bisnis Universitas Udayana (Unud), Bali, Indonesia \\ email:dwipermanasari18@gmail.com /Telp: +62 82145844238 \\ ${ }^{2}$ Fakultas Ekonomi dan Bisnis Universitas Udayana (Unud), Bali, Indonesia
}

\begin{abstract}
ABSTRAK
Nilai perusahaan merupakan faktor bagi manajemen untuk bertindak oportunistik dengan meratakan laba. Tujuan dilakukannya penelitian yaitu mengetahui kemampuan good corporate governance memoderasi pengaruh nilai perusahaan pada praktik perataan laba. Jumlah sampel penelitian selama tahun 2012-2016 pada sektor property dan real estate sebanyak 160 observasian. Metode non probability sampling dengan purposive sampling dipilih dalam penentuan sampel. Proses analisis data dilakukan melalui analisis faktor, uji regresi logistik dan interaksi (MRA). Hasil yang ditemukan yaitu: 1) Nilai perusahaan berpengaruh negatif tetapi tidak signifikan pada perataan laba; 2) Good Corporate Governance tidak mampu memoderasi pengaruh nilai perusahaan pada praktik perataan laba.

Kata Kunci: Nilai perusahaan, praktik perataan laba, good corporate governance
\end{abstract}

\begin{abstract}
Firm value was the factor for management to become opportunistic by doing income smoothing. This research has a purpose to giving an empirical proof about the ability of good corporate governance in moderating the relation between firm value and income smoothing. The number of sample on 2012-2016 period in property and real estate sector was about 160 observations. This study applying non probability with purposive sampling technique. The process of analysis data was through factor analysis and logistic regression with MRA. There were two main result of this research included: 1) firm value negatively influence on income smoothing but not significantly; 2) good corporate governance did not weaken the relation of firm value and income smoothing.
\end{abstract}

Keywords: Firm value, income smoothing, good corporate governance

\section{PENDAHULUAN}

Laporan keuangan adalah sebuah cerminan atas kondisi perusahaan, karena di dalamnya terkandung berbagai informasi yang dibutuhkan baik oleh pihak internal dan juga eksternal sebagai pemangku kepentingan. Menurut Astika (2011: 
80), laporan keuangan didefinisikan sebagai laporan pertanggungjawaban oleh manajemen perusahaan kepada pihak luar perusahaan. Laporan keuangan menyajikan informasi laba yang sangat penting dalam menentukan keputusan baik bagi investor maupun manajemen perusahaan. Hal ini sesuai dengan pernyataan SFAC No. 1 tentang pengungkapan informasi mengenai laba yang merupakan fokus perhatian dalam melakukan penaksiran atas kinerja maupun pertanggungjawaban pihak manajemen perusahaan (Dewantari dan Badera, 2015). Standar Akuntansi Keuangan (SAK) di Indonesia menyediakan pilihan terkait metode atau kebijakan akuntansi yang mampu menggambarkan secara nyata kondisi perusahaan termasuk laba perusahaan, akan tetapi hal tersebut dimanfaatkan oleh manajemen untuk berperilaku yang tidak semestinya yang disebut dengan dysfunctional behavior. Penyebab munculnya dysfunctional behavior dalam konsep agency theory adalah terdapatnya kesenjangan informasi oleh pihak dan prinsipal.

Scott (2006: 296) memaparkan terdapat dua hal yang melatarbelakangi perusahaan melakukan pengelolaan laba diantaranya, pertama pengelolaan laba secara efisien yang bertujuan untuk meningkatkan informasi laba yang bersifat transparan dalam penyampaian hal yang menyangkut internal perusahaan. Kedua adalah tindakan laba yang bersifat oportunistik, mengakibatkan kesalahan pengambilan keputusan oleh investor. Pengelolaan laba secara oportunistik selalu berkaitan dengan konsep teori keagenan, menyangkut tindakan mendahulukan kepentingan pribadi yang menimbulkan adanya konflik keagenan. Teknik 
pengelolaan laba yang memiliki sifat oportunistik oleh manajemen perusahaan cenderung memilih meratakan laba perusahaan.

Nejad, dkk. (2013), memberikan definisi terkait perataan laba (income smoothing) sebagai tindakan sengaja oleh manajemen perusahaan dengan menggunakan kebijakan akuntansi untuk meminimalisir laba yang berfluktuasi. Teknik ini dilakukan oleh perusahaan yang cenderung memilih untuk meratakan laba dengan melakukan pelaporan laba yang tumbuh dengan konsisten atau stabil jika dibandingkan perubahan laba yang mengalami peningkatan atau penurunan secara signifikan. Nilai perusahaan adalah salah satu faktor pendorong terjadinya perataan laba, karena peranan nilai perusahaan sebagai tolak ukur keberhasilan manajemen perusahaan pada periode sebelumnya serta dapat memberikan gambaran perusahaan pada periode berikutnya untuk meyakinkan pemegang saham (Wijaya dan Sunarno, 2015). Proksi nilai perusahaan adalah Price to Book Value (PBV), apabila perusahaan memiliki PBV lebih besar dari satu, perusahaan digolongkan sebagai perusahaan yang mampu menarik berbagai sumber daya termasuk investor (Herawaty,2008). Tingginya nilai perusahaan akan menjadi motivasi tersendiri bagi manajemen meratakan laba perusahaan dengan harapan bahwa nilai perusahaan dapat dipertahankan.

Fenomena yang terjadi pada sektor Property dan Real Estate, berdasarkan survei dari Bank Indonesia yaitu pada tahun 2012 dan 2013 terdapat kenaikan harga property residensial, hingga berlanjut pada kuartal I tahun 2014 sebesar 2,56\% lebih tinggi dibandingkan tahun 2013. Pada tahun 2014 akhir hingga 2015 sektor property mengalami penurunan sehingga berdampak pada pergerakan dari 
nilai perusahaan. Tabel 1 menyajikan nilai perusahaan yang cenderung fluktuatif dalam empat tahun ke belakang.

Tabel 1.

Kenaikan atau penurunan PBV 12 Perusahaan Property dan Real Estatedi BEI tahun 2012-2015

\begin{tabular}{llllll}
\hline No & Perusahaan & \multicolumn{3}{c}{ PBV } \\
\cline { 3 - 6 } & & $\mathbf{2 0 1 2}$ & $\mathbf{2 0 1 3}$ & $\mathbf{2 0 1 4}$ & $\mathbf{2 0 1 5}$ \\
\hline 1 & APLN & 1.43 & 1.19 & 0.61 & 0.87 \\
2 & ASRI & 2.49 & 1.58 & 1.81 & 1.02 \\
3 & BEST & 3.60 & 1.73 & 2.57 & 1.25 \\
4 & COWL & 0.61 & 1.94 & 2.54 & 2.42 \\
5 & EMDE & 0.90 & 0.67 & 0.78 & 0.81 \\
6 & FMII & 2.67 & 3.70 & 4.40 & 4.15 \\
7 & GMTD & 0.29 & 2.09 & 1.29 & 1.29 \\
9 & JPRT & 3.84 & 4.10 & 4.74 & 2.47 \\
10 & LPCK & 1.83 & 1.87 & 2.90 & 1.80 \\
11 & MTLA & 2.63 & 1.63 & 1.76 & 2.07 \\
12 & PWON & 3.46 & 3.17 & 4.57 & 2.53 \\
\hline
\end{tabular}

Sumber: Data diolah, 2017.

Pada Tabel 1 dijelaskan tingginya PBV dari salah satu perusahaan yaitu Jaya Real Property Tbk (JPRT) sebesar 3,84 di tahun 2012 mengalami peningkatan di tahun 2013 dan 2014 sebesar 4,10 dan 4,74, akan tetapi pada tahun 2015 PBV mengalami penurunan hingga 2,47 (sesuai dengan fenomena naik turunnya harga property survei Bank Indonesia). PBV dari perusahaan JPRT memiliki nilai lebih besar dari satu berarti bahwa perusahaan memiliki PBV yang tinggi. PBV yang bernilai lebih besar dari satu menjadi faktor bagi manajemen untuk mempertahankannya, akan tetapi kondisi yang terjadi pada sektor Property dan Real Estate menunjukkan bahwa PBV yang lebih besar dari satu justru cenderung mengalami fluktuasi tinggi. Begitu pula perusahaan lainnya yang mengalami kenaikan mapupun penurunan selama empat tahun terakhir, sehingga mampu menggambarkan ketidakkonsistenan nilai perusahaan yang dapat memengaruhi manajemen untuk melakukan pengelolaan laba pada akhirnya. 
Effendi (2009:1) menyatakan bahwa GCG merupakan sebuah internal control perusahaan yang bertujuan untuk melakukan pengelolaan terhadap risiko yang bersifat signifikan dengan alasan pencapaian tujuan bisnis dengan cara mengamankan aset perusahaan serta peningkatan atas nilai investasi dari pemegang saham dalam jangka panjangnya. Juniarta dan Sujana (2015) berpendapat bahwa mekanisme GCG yang dapat melakukan kontrol terhadapperilaku pengelolaan laba diantaranya; 1) kepemilikan institusional, 2) kepemilkan manajerial, 3) dewan komisaris independen serta 4) komite audit.

Penelitian terkait pengaruh nilai perusahaan pada praktik perataan laba telah banyak diteliti. Beberapa penelitian oleh Suranta dan Merdiusi (2004), Aji dan Mita (2010), Prayudi dan Daud (2013), Peranasari dan Dharmadiaksa (2014) serta penelitian Cahyani (2012), mendapatkan hasil bahwa pengaruh positif serta signifikan dimiliki oleh nilai perusahan pada perataan laba. Namun penelitian dari Pratama (2012), Noviana dan Yuyetta (2012) dan Adi (2015) membuktikan bahwa tindakan perataan laba tidak dipengaruhi oleh nilai perusahaan. Inkonsistensi hasil penelitian terdahulu menjadi alasan bagi peneliti untuk menguji kemampuan GCG memoderasi pengaruh nilai perusahaan pada praktik perataan laba.

Pokok masalah yang dirumuskan mencakup dua masalah utama yaitu pertama apakah nilai perusahaan berpengaruh pada praktik perataan laba? dan kedua apakah GCG mampu memoderasi pengaruh nilai perusahaan pada praktik perataan laba? Adapun tujuan penelitian ini dilakukan yaitu diperolehnya informasi berupa bukti empiris mengenai pengaruh nilai perusahaan pada praktik perataan laba dan bagaimana GCG memoderasi hubungan antara nilai perusahaan 
pada praktik perataan laba. Penelitian ini memiliki dua sisi manfaat meliputi manfaat teoritis yaitu hasil penelitian yang memberikan informasi tambahan berupa teori yang berkaitan dengan perataan laba seperti teori keagenan. Manfaat praktis penelitian adalah sebagai bahan pertimbangan bagi pelaku pasar dalam melakukan analisis terkait informasi fundamental perusahaan sebelum berinvestasi.

Jensen dan Meckling (1976) mengemukakan kontrak diantara manajemen sebagai agen dan pemegang saham sebagai principal adalah sebuah hubungan keagenan. Pada hubungan keagenan manajer sebagai agent mempunyai informasi yang bersifat lebih mendalam dibandingkan dengan para pemegang saham mengenai bagaimana kondisi perusahaan. Ketika kondisi perusahaan kurang menguntungkan manajer akan cenderung tidak memberikan informasi yang berdasarkan dengan fakta atau kondisi nyata perusahaan yang disebut dengan asimetri informasi. Kesenjangan informasi diantara agent dan principal menimbulkan agency conflict yang disebabkan adanya perbedaan kepentingan oleh kedua belah pihak. Perbedaan kepentingan oleh agent dan principal, menyebabkan munculnya keinginan oleh pihak manajemen untuk melakukan praktik manajemen laba (Peranasari dan Dharmadiaksa, 2014).

Menurut (Schipper, 2003) manajemen laba didefinisikan sebagai tindakan intervensi oleh pihak manajemen terhadap pelaporan keuangan perusahaan yang bertujuan untuk memeroleh keuntungan pribadi untuk agent. Definisi lain dari manajemen laba menurut Scott (2006: 344) adalah sebagai sebuah teknik penyajian laba yang memiliki tujuan untuk memaksimalkan utilitas manajemen 
serta meningkatkan nilai pasar dengan memilih serangkaian kebijakan maupun prosedur akuntansi oleh manajemen. Persepsi manajer dalam melakukan tindakan manajemen laba diklasifikasikan menjadi dua: pertama, bertujuan untuk memaksimalkan kepuasan relatif manajemen (opportunistic behavior). Kedua, bertujuan agar semua pemangku kepentingan dalam perusahaan terkait dalam kontrak dapat memeroleh keuntungan (efficient contracting). Salah satu cara melakukan manajemen laba yang bersifat oportunistik adalah dengan meratakan laba.

Perataan laba (income smoothing) menurut Ball dan Brown (1968) merupakan sebuah usaha oleh pihak manajemen untuk melakukan reduksi atas laba yang berfluktuasi, terutama terkait dengan tindakan yang ditujukan untuk mengurangi pelaporan laba yang mengalami peningkatan secara abnormal. Penelitian Eckel (1981) memaparkan bahwa perataan laba dapat diklasifikasikan menjadi dua yaitu; 1) naturally smooth adalah jenis tindakan perataan laba yang berimplikasi pada sifat dari proses terjadinya perataan laba tersebut dengan dihasilkannya suatu aliran laba perusahaan yang stabil atau konstan, dan 2) intentionally smooth, adalah jenis perataan laba yang muncul karena terjadinya keikutsertaan pihak lain yaitu manajemen perusahaan. Intentionally smooth diklasifikasikan menjadi artificial smoothing serta real smoothing.

Gordon (1964) berpendapat motivasi bagi manajemen perusahaan untuk meratakan laba diantaranya; 1) pemilihan metode akuntansi oleh manajemen perusahaan bertujuan untuk memaksimalkan kepuasaan ataupun kesejahteraannya (utilitas manajemen), sehingga metode akuntansi yang digunakan oleh pihak 
manajemen cenderung metode yang memberikan suatu beneficial bagi manajemen sendiri; 2) adanya kegunaan yang sama terkait fungsi keamanan dari pekerjaannya, peringkat di dalam perusahaan hingga tingkat pertumbuhan gaji yang dialami; 3) pemegang saham memeroleh kepuasan atas kinerja manajemen sehingga dapat meningkatkan status maupun penghargaan untuk manajer, meratakan laba dalam hal ini bagi manajer berkaitan dengan bagaimana manajer dapat menikmati keuntungan pribadi yang memiliki sifat financial akibat tindakan mengelola keuangan; dan 4) tingkat pertumbuhan maupun stabilitas laba perusahaan akan menghasilkan kepuasan yang sama bagi semua pihak, sehingga dengan meratakan laba para pemangku kepentingan akan memeroleh kesejahteraannya masing-masing.

Susanto dan Yulius (2016) juga menyatakan bahwa firm value tercermin dari harga sahamnya yang merupakan refleksi atas penenetuan keputusan investasi, tindakan memanajemen aset, hingga menentukan keputusan terkait pendanaan. Tinggi rendahnya harga saham suatu perusahaan menunjukan bagaimana publik dalam menilai kinerja dari nilai perusahaan tersebut. Penelitian ini menggunakan pendekatan market value, yang diukur dengan Price to Book Value (PBV). Beberapa alasan digunakannya PBV sebagai proksi variabel nilai perusahaan meliputi; 1) nilai yang paling intuitif serta cenderung stabil ketika dibandingkan dengan harga pasar; 2) konsistensi standar akuntansi bagi semua perusahaan sehingga dapat dilihat apakah terjadi over atau under valuation pada suatu emiten; 3) laba negatif dapat diukur dengan rasio ini. Tingginya nilai suatu perusahaan dilihat dari seberapa tinggi publik menilai harga saham perusahaan di 
atas nilai bukunya. Hermuningsih dan Wardani (2009) menyatakan bahwa rasio PBVyang berbanding lurus terhadap kepercayaan investor memiliki makna bahwa semakin tinggi rasio PBV maka dapat dikatakan bahwa kepercayaan pasar terhadap prospek perusahaan tersebut semakin tinggi. Sebagian besar keputusan investasi di pasar modal dilakukan berdasarkan informasi akuntansi salah satunya nilai perusahaan, sehingga konsistensi nilai perusahaan menjadi perhitungan bagi investor tersendiri

Good Corporate Governance (GCG) ialah sebuah konsep yang diimplementasikan dengan tujuan untuk melakukan peningkatan atas kualitas kinerja perusahaan (Padachi, 2017). Prinsip-prinsip dasar GCG menurut Organization for Economics Coorporation and Development (OECD) (2004) mencakup enam hal yakni; 1) Menjamin efektiviras kerangka dasar atau basis GCG; 2) Perlindungan hak-hak dari pemegang saham ; 3) Seluruh pemegang saham mendapat perlakuan yang setara; 4) Peran pemangku kepentingan terkait perusahaan; 5) Transparansi serta pengungkapan; 6) Tanggungjawab dari dewan komisaris dan direksi.

Berdasarkan pedoman GCG yang disusun KNKG pada tahun 2006 terdapat lima prinsip yang dikenal di Indonesia mencakup; 1) Transparansi yang memiliki arti adanya keterbukaan informasi di dalam perusahaan misalnya dalam pengambilan suatu keputusan, hingga pengungkapan informasi yang sifatnya material dan relevan terhadap Perseroan; 2) Akuntabilitas bermakna adanya fungsi, sistem, struktur hingga pertaanggungjawaban yang jelas di dalam Perseroan; 3) Pertanggungjawaban merupakan suatu kepatuhan dalam melakukan 
Ni Made Dwi Permanasari dan I Ketut Suryanawa. Kemampuan ...

pengelolaan Perseroan atas peraturan atau Undang-undang yang berlaku; 4) Independensi merupakan sutau situasi dikelolanya Perseroan secara professional yang berarti tidak terdapat benturan kepentingan yang dapat memengaruhi tindakan pengelolaan yang sehat; 5) Keadilan memiliki definsi adanya perlakuan adil dan setara dalam pemenuhan hak dari stakeholder berdasarkan peraturan yang berlaku.

Terkait dengan prinsip GCG, maka mekanisme yang mengontrol tindakan manajemen di dalam perusahaan meliputi 1) Kepemilikan institusional adalah pemangku kepentingan yang memiliki kewenangan untuk melakukan monitor terhadap agentkarena persentase sahamnya yang besar di dalam perusahaan, sehingga berimplikasi pula pada keinginan mengatur laba oleh manajemen menurun Moh'd et al (1998); 2) Kepemilikan Manajerial menurut Bathala (1997) dapat menekan tindakan perataan laba karena persentase kepemilikan manajerial yang besar secara implisit menjadi alasan bagi manajemen untuk tidak melakukan tindakan oportunistik tersebut sebab akan membahayakan perusahaan dalam jangka panjang; 3) Dewan Komisaris Independen merupakan komisaris eksternal yangmampu meminimalisir terjadinya perataan laba, apabila jumlah dewan komisaris independen semakin banyak maka akan terjadi peningkatan pengawasan pada manajemen perusahaan (Klein, 2002); 4) Komite Audit bertugas melakukan pengamatan pada pengendalian internal, melakukan pengawasan audit eksternal hingga pengawasan terhadap laporan keuangan guna sebagai tindakan perventif untuk perilaku-perilaku opportunistic. 
Suranta dan Merdistuti (2004), menemukan bahwatingginya nilai pasar perusahaan akan memberikan dampak terhadap kecenderungan manajemen untuk meratakan laba, hal ini dikarenakan perusahaan memiliki keinginan untuk menjaga stabilitas laba. Kemudian, Herawaty (2008) menyatakan bahwa apabila hasil nilai perusahaan dapat dipertahankan dan memiliki nilai lebih dari satu, dapat disimpulkan bahwa perusahaan mampu membawa sumber daya potensial ke dalam perusahaan.Berdasarkan hubungan yang telah dijelaskan, hipotesis penelitian pertama dapat dirumuskan berikut.

$\mathrm{H}_{1} \quad$ : Nilai Perusahaan berpengaruh positif pada praktik perataan laba.

Nilai perusahaan adalah salah satu faktor bagi pihak manajer perusahaan untuk melakukan tindakanmeratakan laba, karena hubungan nilai perusahaan dan praktik perataan laba berbanding lurus.Perataan laba oleh manajemen perusahaan bersifat oportunistik sehingga informasi yang dihasilkan menyesatkan bagi para pihak yang berkepentingan. Menurut Marpaung dan Latrini (2014) untuk meminimalisir perilaku manajer perusahaan untuk menglola laba, perusahaan dapat menerapkan mekanisme GCG. Noronha et. al. menemukan bahwa GCG berperan menekan tindakan pengelolaan laba.

$\mathrm{H}_{2}$ : Good Corporate Governance (GCG) memerlemah pengaruh nilai perusahaan pada praktik perataan laba.

\section{METODE PENELITIAN}

Pendekatan kuantitatif asosiatif merupakan desain penelitian yang dipergunakan. Metode penelitian kuantitatif memiliki pengertian sebagai sebuah metode penelitian berdasarkan pada kenyataan dan digunakan untuk melakukan penelitian 
pada populasi atau sampel tertentu. Pendekatan kuantitatif dengan bentuk asosiatif berdasarkan tipe kausalitas adalah jenis penelitian yang memberikan penjelasan mengenai pengaruh variabel bebas terhadap variabel terikat (Sugiyono, 2016: 12). Lokasi penelitian yaitu pada perusahaan yang termasuk sektor Property dan Real Estate di BEI 2012 hingga 2016 yang diakses melalui website resmi IDX. Objek penelitian dalam penelitian ini yaitu praktik perataan laba tahun 2012 sampai tahun 2016 yang diuji dengan nilai perusahaan dengan GCG sebagai variabel moderator.

Berdasarkan rumusan masalah serta hipotesis penelitian yang telah dipaparkan, dapat diidentifikasi Praktik perataan (Y) sebagai variabel dependen yang memiliki definisi sebagai tindakan manajemen untuk mereduksi naik turunnya laba yang dilakukan secara transaksional atau artificial. Indeks Eckel digunakan dalam penelitian guna menggolongkan perusahaan perata dan bukan perata laba. Untuk mempermudah peneliti, perusahaan skor 1 diberikan pada perusahaan perata, dan skor 0 diberikan pada perusahaan bukan perata. Praktik Perataan Laba dapat dirumuskan sebagai berikut:

Indeks Perataan Laba (IPL) $=\frac{C V \Delta I}{C V \Delta S}$.

Keterangan:

$\Delta \mathrm{I} \quad=$ Perubahan laba dalam satu periode

$\Delta \mathrm{S} \quad=$ Perubahan penjualan dalam satu periode

$\mathrm{CV}=$ Koefisien variasi

$\mathrm{CV} \Delta \mathrm{I}$ dan $\mathrm{CV} \Delta \mathrm{S}$ dirumuskan sebagai berikut:

$\mathrm{CV} \Delta \mathrm{I}$ dan $\mathrm{CV} \Delta \mathrm{S}=\sqrt{\frac{\sum(\Delta X-\Delta \bar{X})^{2}}{n-1}} / \Delta \bar{X}$ 
Keterangan:

$\Delta X \quad=$ Perubahan laba atau penjualan antara tahun $\mathrm{n}$ ke tahun $\mathrm{n}-1$

$\Delta \bar{X} \quad=$ Perubahan rata-rata laba atau penjualan antara tahun $\mathrm{n}$ ke tahun $\mathrm{n}-1$

$\mathrm{N} \quad=$ Periode pengamatan

Pada saaat hasil indeks perataan laba (IPL) lebih kecil dari satu, maka perusahaan tersebut masuk ke dalam perusahaan perata laba serta diberi skor1. Sebaliknya jika IPL lebih besar sama dengan satu, maka perusahaan tersebut termasuk ke dalam perusahaan tidak perata laba dan diberi skor 0 (Prabayanti dan Gerianta, 2011).

Nilai Perusahaan (X1) sebagai variabel independen memiliki pengertian sebagai penilaian publik terhadap kinerja perusahaan pada periode sebelumnya dan prospek perusahaan pada periode berikutnya, yang tercermin dari harga sahamnya dinilai dengan PBV yang disajikan pada rumus dibawah ini.

Price to Book Value $(\mathrm{PBV})=\frac{\text { Harga Pasar Per Lembar Saham }}{\text { Nilai Buku Per Lembar Saham }}$

GCG (X2) sebagai variabel moderasi diwakili oleh empat proksi yang yang masing-masing dirumuskan sebagai berikut:

$$
\begin{aligned}
& \mathrm{KI}=\frac{\text { jumla } h \text { saham yang dimiliki institusional }}{\text { Total saham beredar }} \times 100 \% . \\
& \mathrm{KM}=\frac{\text { Jumla } h \text { saham yang dimiliki manajemen }}{\text { Total saham bereda } r} \times 100 \% \\
& \mathrm{IN}=\frac{\text { Jumla } h \text { Dewan Komisaris Independen }}{\text { Jumla h Anggota Dewan Komisaris }} \times 100 \% \ldots \ldots \\
& \mathrm{KA}=\frac{\text { Jumla } h \text { Komite Audit }}{\text { Jumla } h \text { Anggota Dewan Komisaris }} \times 100 \% \ldots . . .
\end{aligned}
$$

Laporan keuangan yang telah diaudit serta diakses melalui web resmi BEI merupakan bentuk data kuantitatif dan sekunder dipergunakan pada penelitian ini. 
Ni Made Dwi Permanasari dan I Ketut Suryanawa. Kemampuan ...

Penentuan sampel dari populasi penelitian dipilih metode non probability sampling dan purposive sampling dengan menyertakan beberapa kriteria mencakup: 1) Laporan keuangan diterbitkan berturut-turut; 2) Laporan keuangan tutup buku pada tanggal 31 Desember; 3) Perusahaan tidak mengalami rugi secara berturut-turut; 4) Perusahaan yang memiliki data variabel proksi GCG. Berdasarkan kriteria tersebut jumlah observasi yang diperoleh untuk penelitian adalah sebanyak 32 perusahaan dengan 160 total obseravasian. Pada penelitian ini mempergunakan metode pengumpulan data observasi nonpartisipan serta dilakukan Uji Statistik Deskriptif, Analisis Faktor hingga Uji Regresi Logistik dan Uji Interaksi yang menghasilkan persamaan sebagai berikut.

$\frac{\operatorname{Ln}(P)}{1-P}=\alpha+\beta X 1+\beta X 2-\beta X 1 X 2+e$

Keterangan :

$\frac{\operatorname{Ln}(P)}{1-P}=$ Dummy variabel Perataan Laba

$\alpha \quad=$ Koefisien konstanta

$\beta 1-\beta 2=$ Koefisiens regresi

$\mathrm{X} 1=$ Price to Book Value $(\mathrm{PBV})$

$\mathrm{X} 2=$ Good Corporate Governance (GCG)

$\mathrm{X} 1 \mathrm{X} 2$ = PBV_GCG

$e=$ Error term

\section{HASIL DAN PEMBAHASAN}

Pada tabel 2 di bawah ditampilkan data informasi masing-masing variabel penelitian. Perataan Laba sebagai objek penelitian memiliki mean sebesar 0,3438. Dapat ditunjukkan bahwa dari 160 sampel penelitian terdapat 55 sampel melakukan praktik perataan laba (kode 1), sedangkan perataan laba tidak dilakukan pada 105 sampel yang tersisa (kode 0). Nilai minimum yang dimiliki 
PBV yaitu sebesar 0,29 (Gowa Makasar Tourism Development Tbk pada tahun 2012) sedangkan nilai maksimum sebesar 8,30 (Plaza Indonesia Realty Tbk pada tahun 2016). Rata-rata PBV adalah 1,9469 dengan simpangan baku sebesar 1,56816. Good Corporate Governance (GCG) memiliki nilai minimum sebesar 4,47 (Kawasan Industri Jababeka Tbk pada tahun 2014) dan nilai maksimumnya sebesar 1,47 (Plaza Indonesia Realty Tbk pada tahun 2015). Mean nilai faktor GCG sebesar 0,0000 dengan nilai simpangan baku sebesar 1,0000. Interaksi GCG dan PBV memiliki nilai minimum sebesar -7,35 (Pakuwon Jati Tbk pada tahun 2014) sedangkan nilai maksimum sebesar 11,77 (Plaza Indonesia Realty Tbk pada tahun 2016) dengan deviasi sebesar 2,41944

Tabel 2.

Hasil Uji Statistik Deskriptif

\begin{tabular}{lccccc}
\hline & N & Minimum & Maximum & Mean & Std. Deviation \\
\hline IPL & 160 & 0,00 & 1,00 & 0,3438 & 0,47645 \\
PBV & 160 & 0,29 & 8,30 & 1,9469 & 1,56816 \\
GCG & 160 & $-4,47$ & 1,47 & 0,0000 & 1,00000 \\
PBV_GCG & 160 & $-7,35$ & 11,77 & 0,1090 & 2,41944 \\
\hline
\end{tabular}

Sumber: Data diolah, 2017.

Variabel GCG digunakan sebagai variabel moderasi mencakup empat proksi kemudian difaktorkan untuk mencari faktor yang paling mewakili GCG. Hasil analisis faktor keempat disajikan pada Tabel 3 sampai Tabel 9 berikut.

Tabel 3.

Hasil Uji Total Variance Explained Variabel GCG

\begin{tabular}{|c|c|c|c|c|c|c|}
\hline \multirow[t]{2}{*}{ Comp. } & \multicolumn{3}{|c|}{ Initial Eigen values } & \multicolumn{3}{|c|}{ Extraction Sums of Squared Loadings } \\
\hline & Total & $\begin{array}{c}\text { \% of } \\
\text { Variance }\end{array}$ & Cumulative \% & Total & $\begin{array}{c}\text { \% of } \\
\text { Variance }\end{array}$ & $\begin{array}{c}\text { Cumulative } \\
\%\end{array}$ \\
\hline 1 & 1,436 & 35,908 & 35,908 & 1,436 & 35,908 & 35,908 \\
\hline 2 & 1,122 & 28,043 & 63,951 & & & \\
\hline 3 & 1,010 & 25,239 & 89,190 & & & \\
\hline 4 & 0,432 & 10,810 & 100,000 & & & \\
\hline
\end{tabular}

Sumber: Data diolah, 2017 
Ni Made Dwi Permanasari dan I Ketut Suryanawa. Kemampuan ...

Tabel 3 menyajikan hasil analisis faktor dengan nilai eigen value lebih besar dari satu serta variance hanya dapat dijelaskan sebesar 35,908\%, sehingga komponen terbentuk digolongkan belum sesuai, oleh karena itu proksi yang tidak tepat dieliminasi dari analisis faktor berdasarkan nilai communalitiesnya.

Tabel 4.

Ringkasan Nilai Loading Factor dan Communalities dari Masing- masing Proksi GCG

\begin{tabular}{ccc}
\hline \multicolumn{3}{c}{ Good Corporate Governance } \\
\hline Proksi & Factor Loading & Communalities \\
\hline Kepemilikan Institusional & $-0,582$ & 0,338 \\
Kepemilikan Manajerial & $-0,181$ & 0,033 \\
Dewan Komisaris Independen & 0,896 & 0,803 \\
Komite Audit & 0,512 & 0,262 \\
\hline
\end{tabular}

Sumber: Data diolah, 2017

Pada Tabel 4 dapat diketahui kepemilikan manajerial memiliki nilai communalities terkecil yaitu 0,033. Proksi kepemilikan manajerial harus dieliminasi, dan analisis faktor kembali dilakukan dengan hanya menyertakan tiga proksi agar menghasilkan faktor yang sesuai dengan kriteria validitas konstruk.

Tabel 5.

Hasil Uji Total Variance Explained Variabel GCG Setelah Kepemilikan Manajerial dikeluarkan

\begin{tabular}{lcccccc}
\hline Comp. & \multicolumn{3}{c}{ Initial Eigenvalues } & \multicolumn{2}{c}{$\begin{array}{c}\text { Extraction Sums of Squared } \\
\text { Loadings }\end{array}$} \\
\hline & Total & $\begin{array}{c}\text { \% of } \\
\text { Variance }\end{array}$ & $\begin{array}{c}\text { Cumulative } \\
\text { \% }\end{array}$ & Total & $\begin{array}{c}\text { \% of } \\
\text { Variance }\end{array}$ & Cumulative \\
& & 47,571 & 47,571 & 1,427 & 47,571 & 47,571 \\
\hline 1 & 1,427 & 36,022 & 83,593 & & & \\
3 & 1,081 & 16,407 & 100,000 & & & \\
\hline
\end{tabular}

Sumber: Data diolah, 2017

Analisis faktor selanjutnya dilakukan dengan menggunakan tiga proksi sesuai pada Tabel 5 yang menunjukkan nilai eigen value lebih besar dari satu namun varians dapat dijelaskan hanya sebesar $47,571 \%$, masih berada dibawah $60 \%$, sehingga komponen masih belum sesuai. 
Tabel 6.

Ringkasan Nilai Loading Factor dan Communalities dari Masing-masing Proksi GCG Setelah Kepemilikan Manajerial Dikeluarkan

\begin{tabular}{ccc}
\hline \multicolumn{3}{c}{ Good Corporate Governance } \\
\hline Proksi & Factor Loading & Communalities \\
\hline Kepemilikan Institusional & $-0,585$ & 0,343 \\
Dewan Komisaris Independen & 0,880 & 0,775 \\
Komite Audit & 0,556 & 0,310 \\
\hline
\end{tabular}

Sumber: Data sekunder diolah, 2017

Hasil analisis faktor terhadap ketiga proksi yang tersisa berdasarkan Tabel 6 diketahui bahwa komite audit memiliki nilai communalities terkecil yaitu sebesar 0,310. Proksi komite audit yang memiliki nilai communalities terkecil harus dieliminasi, kemudian analisis faktor kembali dilakukan dengan hanya menyertakan dua proksi yaitu kepemilikan institusional dan dewan komisaris independen. Hasil analisis faktor setelah dilakukan eliminasi komite audit disajikan pada Tabel 7, 8, 9 .

Berdasarkan Tabel 7 dibawah ini besarnya nilai Barlett Test of Sphericity telah memenuhi kriteria yaitu signifikansi $\leq 0,05$. Nilai statistik diketahui sebesar 18,743 dengan signifikansi sebesar 0,000 menampilkan adanya hubungan signifikan terjadi antar proksi. Besarnya nilai Kaiser-Meyer-Olkin (KMO) yakni 0,5 telah sesuai dengan kriteria yang mengindikasikan ukuran sampel tergolong kategori baik.

Tabel 7.

Hasil Uji KMO dan Bartletts Test Variabel GCG

\begin{tabular}{lcc}
\hline Kaiser-Meyer-Olkin Measure of Sampling Adequacy. & 0,500 \\
Bartlett's Test of Sphericity & Approx. Chi Square & 18,743 \\
& Df & 1 \\
& Sig & 0,000 \\
\hline
\end{tabular}

Sumber: Data diolah, 2017. 
Tabel 8.

Hasil Uji Total Variance Explained Variabel GCG Setelah Komite Audit Dikeluarkan

\begin{tabular}{ccccccc}
\hline Comp. & \multicolumn{3}{c}{ Initial Eigenvalues } & \multicolumn{2}{c}{$\begin{array}{c}\text { Extraction Sums of Squared } \\
\text { Loadings }\end{array}$} \\
\hline & Total & $\begin{array}{c}\text { \% of } \\
\text { Variance }\end{array}$ & $\begin{array}{c}\text { Cumulative } \\
\text { \% }\end{array}$ & Total & $\begin{array}{c}\text { \% of } \\
\text { Variance }\end{array}$ & $\begin{array}{c}\text { Cumulative } \\
\%\end{array}$ \\
\hline 1 & 1,335 & 66,748 & 66,748 & 1,335 & 66,748 & 66,748 \\
2 & 0,665 & 33,252 & 100,000 & & & \\
\hline
\end{tabular}

Sumber: Data sekunder diolah, 2017.

Tabel 8 menyajikan faktor yang diperoleh memiliki nilai eigen value $>1$ dan varians dapat dijelaskan sebesar $66,748 \%$, sehingga terbentuk kesesuaian pada komponen tersebut.

Tabel 9.

Hasil Analisis Faktor

\begin{tabular}{ccc}
\hline \multicolumn{3}{c}{ Good Corporate Governance } \\
\hline Proksi & Factor Loading & Communalities \\
\hline Kepemilikan Institusional & 0,817 & 0,667 \\
Kepemilikan Manajerial & $-0,817$ & 0,667 \\
\hline
\end{tabular}

Sumber: Data sekunder diolah, 2017.

Tabel 9 menjelaskan bahwa loading factor semua proksi > 0,50. Hasil ini menunjukkan pula proksi variabel GCG adalah variabel yang kuat, sesuai dengan hasil analisis faktor bahwa proksi yang dipilih untuk mewakili GCG adalah kepemilikan institusional dan dewan komisaris independen. Penelitian terdahulu oleh Agustia (2013) dan Chen et. al. (2015) menyatakan kepemilikan institusional merupakan proksi yang mampu mewakili GCG dalam meningkatkan kualitas perusahaan mengingat persentase kepemilikan yang besar atau mayor dari pihak institusional akan menimbulkan suatu pengawasan dan monitoring yang lebih efektif. Disisi lain sebagai pemilik mayoritas, pihak institusional tentunya ingin mengetahui lebih perusahaan yang menjadi tempatnya berinvestasi sehingga dengan suara yang signifikan dalam RUPS dapat mengendalikan manajemen 
untuk melakukan pengelolaan laba yang sifatnya oportunistik. Proksi kedua yang terpilih yaitu ukuran dewan komisaris independen juga merupakan proksi yang baik untuk mewakili GCG. Menurut Novitaningrum dan Amboningtyas (2017) komisaris independen dapat membantu perusahaan menjamin efektivitas GCG dengan alasan bahwa komisaris independen mampu memberikan pengaruh terhadap integritas laporan keuangan yang dihasilkan untuk meningkatkan kepercayaan pemangku kepentingan, selain itu, komisaris independen juga memiliki tugas menilai kinerja perusahaan secara luas dan keseluruhan.

Analisis data selanjutnya dilakukan dengan uji regresi logistik dan uji interaksi (MRA) dengan alasan bahwa variabel dependen berbentuk variabel dummy. Uji regresi logistik melalui beberapa tahapan pengujian meliputi: Pengujian atas kelayakan model regresi digunakan Uji Hosmer dan Lemeshow pada Tabel 10.

Tabel 10.

Hasil Uji Hosmer dan Lemeshow Test

\begin{tabular}{cccc}
\hline Step & Chi-square & $\boldsymbol{d f}$ & Sig. \\
\hline 1 & 9,510 & 8 & 0,301 \\
\hline
\end{tabular}

Sumber: Data sekunder, diolah 2017

Tabel 10 memperlihatkan besar Chi-square sebesar 9,510 dan tingkat signifikansinya > 0,05 yaitu 0,301, maka dapat dinyatakan model dapat diterima, sebab model terbentuk telah sesuai dengan data observasian. Selanjutnya analisis dilakukan dengan menilaikeseluruhan model regresi dengan membandingkan nilai -2 log likehood diawal dan akhir.

Tabel 11.

Hasil Perbandingan -2LL Awal dengan -2LL Akhir

\begin{tabular}{l|c}
\hline -2LL awal (Block Number $=0)$ & 205,917 \\
\hline -2LL akhir (Block Number $=1)$ & 195,625 \\
\hline \multicolumn{2}{l}{ Sumber: Data sekunder diolah, 2017. }
\end{tabular}


Tabel 11 menjelaskan nilai -2LLawal sebesar 205,917 mengalami penurunan hingga 195,625. Turunnya nilai log likehood (-2LL), memiliki arti model regresi yang dihipotesiskan sesuai dengan data. Pengujian kemudian dilanjutkan dengan menginterpretasikan besaran koefisien determinasi $\left(\mathrm{R}^{2}\right)$ menggunakan besarnya Nagelkerke $R$ Square sesuai pada Tabel 12 berikut.

Tabel 12.

Hasil Uji Koefisien Determinasi (Nagelkerke R Square)

\begin{tabular}{cccc}
\hline Step & $\mathbf{- 2}$ Log likelihood & $\begin{array}{c}\text { Cox \& Snell R } \\
\text { Square }\end{array}$ & Nagelkerke R Square \\
\hline 1 & $195,625^{\mathrm{a}}$ & 0,062 & 0,086 \\
\hline Sumber: Data sekunder diolah, 2017. & &
\end{tabular}

Nilai Nagelkerke $R$ Squares ebesar 0,086 yang disajikan pada Tabel 12 yang berarti variabilitas dari variabel dependen yaitu sebesar 8,6\% mampu dijelaskan melalui variabel dependen, sedangkan 91,4\% dapat dijelaskan oleh variabel yang berada diluar cakupan penelitian. Pengujian berikutnya mengenai matriks klasifikasi akan menjelaskan bagaimana kekuatan model regresi yang terbentukguna memprediksi probabilitas praktik perataan laba oleh perusahaan yang ditampilkan pada tabel dibawah ini.

Tabel 13.

Hasil Analisis Matriks Klasifikasi

\begin{tabular}{|c|c|c|c|c|c|}
\hline & \multirow{3}{*}{\multicolumn{2}{|c|}{ Observasi }} & \multicolumn{3}{|c|}{ Prediksi } \\
\hline & & & \multicolumn{2}{|c|}{ Perataan Laba } & \multirow{2}{*}{$\begin{array}{c}\text { Persentase } \\
\text { Benar }\end{array}$} \\
\hline & & & $\begin{array}{c}\text { Tidak } \\
\text { Perataan }\end{array}$ & Perataan & \\
\hline \multirow[t]{3}{*}{ Step 1} & \multirow[t]{2}{*}{ IPL } & Tidak Perataan & 97 & 8 & 92,4 \\
\hline & & Perataan & 47 & 8 & 14,5 \\
\hline & \multicolumn{2}{|c|}{ Persentase Keseluruhan } & & & 65,6 \\
\hline
\end{tabular}
Sumber: Data diolah, 2017.

Berdasarkan hasil analisis matriks klasifikasi yang ditunjukkan pada Tabel 13, dijelaskan bahwa adanya prediksi sebesar 92,4\% kemungkinan perusahaan tidak meratakan laba. Hal tersebut memiliki makna dari total observasi sebanyak 
105 perusahaan yang tidak meratakan laba diketahui 97 diantaranya diprediksi tidak meratakan laba, sisanya sebanyak 8 observasian meratakan laba. Kekuatan prediksi kemungkinan melakukan perataan laba adalah sebesar 14,5\%. Hal tersebut menunjukkan dari total observasi sebanyak 55 perusahaan yang meratakan laba diketahui 8 total observasi meratakan laba, sedangkan 47 total observasi sisanya tidak meratakan laba dengan persentase keseluruhan sebesar $65,6 \%$.

Regresi logistik yang terbentuk memberikan hasil berupa nilai signifikansi dan nilai koefisien regresi. Tabel 14 menyajikan hasil dari pengujian regresi logistik dan interaksi.

Tabel 14.

Rangkuman Uji Regresi Logistik dan Uji Interaksi

\begin{tabular}{lllcl}
\hline Variabel & B & Wald & Sig. & Keterangan \\
\hline PBV & $-0,088$ & 0,419 & 0,517 & Tidak Signifikan \\
GCG & 0,739 & 4,132 & 0,042 & Signifikan \\
PBV_GCG & $-0,083$ & 0,311 & 0,577 & Tidak Signifikan \\
Constant & $-0,528$ & & & \\
\hline
\end{tabular}
Sumber: Data diolah, 2017.

Berikut merupakan persamaan dari hasil analisis data Model Regresi,yaitu:

$$
\frac{\operatorname{Ln}(P)}{1-P}=-0,528-0,088 P B V+0,739 G C G-0,083 P B V_{-} G C G+e
$$

Berdasarkan model regresi diatas dapat diinterprestasikan masing-masing variabel sebagai berikut. Koefisien regresi yang dimiliki oleh nilai perusahaan yaitu sebesar -0,088 yang memiliki makna ketika terjadi kenaikan satu satuan nilai perusahaan, kecenderungan perusahaan meratakan laba akan semakin kecil. Variabel PBV memiliki signifikansi 0,517>0,05 maka $\mathrm{H}_{1}$ ditolak, atau nilai perusahaan tidak memiliki pengaruh pada praktik perataan laba. Arah negatif 
koefisien regresi PBV dapat dijelaskan melalui kondisi data perusahaan periode pengamatan 2012-2016 pada sektor Property dan Real Estate. Hasil statistik deskriptif menunjukkan nilai maksimum dan minimum perusahaan sampel, seperti PT Plaza Indonesia Realty Tbk pada tahun 2016 memiliki PBV tertinggi yaitu sebesar 8,30 dan nilai indeks eckel $>1$ sehingga perusahaan cenderung tidak meratakan laba. Di sisi lain, nilai minimum PBV milik PT Gowa Makasar Tourism Development Tbk pada tahun 2012 yaitu sebesar 0,29 dan nilai indeks eckel $<1$ sehingga perusahaan cenderung meratakan laba. Berdasarkan pemaparan hubungan antara nilai perusahaan dan praktik perataan laba yang memiliki arah negatif, dapat disimpulkan bahwa PBV yang tinggi dimiliki oleh perusahaan akan cenderung mengurangi tindakan untuk meratakan laba, sebab PBV yang tinggi telah mencerminkan kinerja manajemen perusahaan yang baik serta tujuan awal dilakukannya perataan laba adalah untuk meningkatkan PBV telah tercapai begitu pula sebaliknya.

Koefisien regresi variabel moderasi antara nilai perusahaan danGCG sebesar -0,083 memilikinilai signifikansi yaitu sebesar 0,577> $\alpha$ (5\%). Hal tersebut menunjukkan bahwa $\mathrm{H}_{2}$ ditolak serta secara statistik GCG tidak mampu memoderasi pengaruh nilai perusahaan pada praktik perataan laba. Penelitian ini menunjukkan hasil yang bertentangan terhadap teori keagenan bahwa implementasi GCG dapat meminimalisir tindakan meratakan laba. Penelitian ini mendukung penelitian terdahulu oleh Putri (2012) serta Butar dan Sudarsi (2012) dengan hasil bahwa kepemilikan institusional tidak dapat membuktikan kemampuannya untuk mengurangi praktik perataan laba. Kepemilikan 
institusional sebagai proksi variabel GCG seharusnya dapat bertindak sebagai pihak eksternal yang melakukan monitoring atas kinerja manajemen. Proksi kedua yang mewakili GCG adalah dewan komisaris independen juga belum mampu mengontrol tindakan manajer. Penelitian oleh Juniarta dan Sujana (2015) menemukan kuantitas maupun penambahan jumlah dewan komisaris independen berguna untuk mememuhi standar regulasi GCG yang berlaku, disisi lain eksistensi dari pemegang saham mayoritas memiliki kendali sehingga kinerja dewan komisaris independen justru mengalami penurunan. Menurut Putra (2014) diangkatnya dewan komisaris independen pada suatu perusahaan kemungkinan bertujuan dalam memenuhi peraturan yang berlaku, akan tetapi tidak untuk meningkatkan kualitas pelaksanaan GCG, sehingga kuantitas dewan komisaris independen tidak memengaruhi hubungan nilai perusahaan dengan tindakan meratakan laba yang dilakukan manajemen perusahaan.

Implikasi penelitian ini dibagi atas dua jenis; 1) implikasi teoritis yang menjadi sumber referensi penelitian yang memiliki hasil berbeda dengan teori keganenan. Perbedaan hasil studi empiris penelitian menunjukkan bahwa penelitian yang memiliki kaitan dengan perataan laba membutuhkan perhatian khusus pada karakteristik perusahaan yang menjadi objek penelitian sebelum menentukan variabel prediktor atau moderasinya. 2) implikasi praktis hasil penelitian sebagai pertimbangan bagi investor dalam mengambil keputusan investasi yang tidak hanya berpusat pada informasi laba, karena dengan adaya perataan laba mengindikasikan informasi bersifat tidak reliable dan relevan. Pihak investor hendaknya memperhatikan pula faktor-faktor lain dalam berinvestasi 
karena dilihat dari kecilnya nilai koefisien determinasi penelitian ditunjukkan bahwa terdapat begitu banyak faktor lain yang menjadi alasan bagi manajemen untuk meratakan laba.

\section{SIMPULAN}

Berikut merupakan simpulan yang dapat diambil: 1) Variabel nilai perusahaan berpengaruh negatif tetapi tidak signifikan pada perataan laba; 2) GCG tidak mampu memoderasi pengaruh nilai perusahaan pada perataan laba, hal ini disebabkan karena kuantitas dari proksi GCG belum menjamin kinerja yang baik pada perusahaan sehingga GCG tidak dapat memerlemah terjadinya praktik perataan laba pada perusahaan.

Adapun beberapa hal yang dapat disarankan sesuai dengan hasil pembahasan hingga kesimpulan yang disajikan pada penelitian ini meliputi: 1) Emiten yang terdaftar dalam sektor Property dan Real Estate di BEI sebaiknya menghindari praktik perataan labadan semaksimal mungkin meningkatkan kualitas laba perusahaan, sehingga asimetri informasi dapat diminimalisir agar tercipta informasi yang benar dan jelas bagi para investor selaku penanam modal.

2) Para investor dan calon investor diharapkan mampu memahami laporan keuangan tahunan publikasian agar mendeteksi praktik perataan labaserta mampu mengetahui bagaimana kualitas laba perusahaan. Investor seharusnya tidak bersikap spekulatif, akan tetapi bersikap rasional dengan cara menganalisis aspek fundamental perusahaan meliputi hasil analisis rasio keuangan. 3) diharapkan peneliti selanjutnya mampu membuat objek penelitian semakin luas terkait segi bidang usaha, periode penelitian, maupun jumlah variabel penelitiannya yang 
dapat memengaruhi variabel terikat seperti profitabilitas, leverage, ukuran perusahaan dan variabel lainnya.

\section{REFERENSI}

Adi, Prima Sapta. 2015. Pengaruh Profitabilitas, Risiko Keuangan, Nilai Perusahaan, Kepemilikan Manajerial, dan Dividend Payout Ratio terhadap Praktik Perataan Laba (Studi Empiris pada Perusahaan Real Estate dan Properti yang Terdaftar Di Bursa Efek Indonesia Tahun 2011-2013). JOM FEKON. 2 (1).

Aji, Dhamar Yudho., dan Aria Farah Mita. 2010. Pengaruh Profitabilitas, Risiko Keuangan, Nilai Perusahaan, Dan Struktur Kepemilikan Terhadap Praktek Perataan Laba: Studi Empiris Perusahaan Manufaktur Yang Terdaftar Di BEI. Simposium Nasional Akuntansi (SNA) XIII: Purwokerto.

Astika, I.B. Putra. 2011. Teori Akuntansi: Konsep-Konsep Dasar Akuntansi Keuangan. Denpasar: Udayana University Press.

Ball, R., and P. Brown. 1968. An Empirical Evaluation of Accounting Income Numbers. Journal of Accounting Research, pp. 159-178.

Bank Indonesia. 2017. Survei Harga Properti Residensial. Jakarta: Bank Indonesia.

Butar, Linda Kurniasih dan Sudarsi Sri. 2012. Pengaruh Ukuran Perusahaan, Profitabilitas, Leverage, dan Kepemilikan Institusional terhadap Perataan Laba: Studi Empiris pada Perusahaan Food and Beverages yang terdaftar di BEI. Dinamika Akuntansi, Keuangan, dan Perbankan, 1(2), h. 143-158.

Cahyani, Nuvita Dwi. 2012. Pengaruh Profitabilitas, Risiko Keuangan, Nilai Perusahaan, Struktur Kepemilikan, Ukuran Perusahaan dan Jenis Industri terhadap Praktek Perataan Laba pada Perusahaan yang Terdaftar Di Bursa Efek Indonesia Periode Tahun. 2005-2010. JURAKSI, 1(2).

Carlson, S. J., dan Chenchuramaiah, T. B. (1997). Ownership Differences and Firms Income Smoothing Behavior. Journal of Business Finance \& Accounting, 24 (2), pp. $179-191$.

Chen et. at. 2015. Institutional Ownership, Income Smoothing, and the Value relevance of Accounting Numbers. Management Review, (35), hal. 109134.

Chung, R., Firth, M., Kim, J.B. 2002. Institutional Monitoring and Opportunistic Earnings Management. Journal of Corporate Finance, pp. 29-48.

Dewantari, Ni Putu Santi dan Badera I Dewa Nyoman. 2015. Good Corporate Governance, Ukuran Perusahaan, Dan Financial Leverage Sebagai Prediktor Perataan Laba. Jurnal Akuntansi Universitas Udayana. 
Eckel, Norm. 1981. The Income Smooting Research Hypothesis Revisited. Journal ABACUS. pp: $28-40$.

Effendi, Muh. Arief. 2009. The Power of Good Corporate Governance Teori dan Implementasi. Jakarta: Salemba Empat.

Gordon, Myron J. 1964. Postulate Principles and Research in Accounting. Accounting Review.

Herawaty, Vinola. 2008. Peran Praktek Corporate Governance sebagai Moderating Variable dari Pengaruh Earnings Management Terhadap Nilai Perusahaan. Simposium Nasional Akuntansi.

Hermuningsih, Sri dan Dewi Kusuma Wardani. (2009). Faktor-Faktor yang Mempengaruhi Nilai Perusahaan pada Perusahaan yang Terdaftar Di Bursa Efek Malaysia dan Bursa Efek Indonesia.Jurnal Siasat Bisnis, 13(2), hal. 173-183.

Jensen, M. and W. Meckling. 1976. Theory of the Firm: Managerial Behavior, Agency,and Ownership Structure.Journal of Financial Economic, pp.305-36.

Juniarta, I Wayan Agus dan Sujana, I Ketut. 2015. Pengaruh Financial Leverage Pada Income Smoothing Dengan Good Corporate Governance Sebagai Variabel Pemoderasi. Jurnal Akuntansi Universitas Udayana, hal. 921939.

Komite Nasional Kebijakan Governance (KNKG). 2006. Pedoman Umum Good Corporate Governance Indonesia. Jakarta. Diakses tanggal 10 Juli 2017.

Klein, A. 2002. Audit Committee, Board of Directors characteristic and Earning management. Journal of Accounting and Economics, 33, pp. 375-400.

Koch S. Cruce. 1981. Income Smoothing; An Experiment. The Accounting Review, 56 (3), pp. 574-586.

Marpaung, c.o., \& Latrini, Y. 2014. Pengaruh Dewan Komisaris Independen, Komite Audit, Kualitas Audit, Dan Kepemilikan Manajerial Pada Perataan Laba. E-Jurnal Akuntansi Universitas Udayana, 7(2), hal. 279-289.

Mohed Mahmoud A., Perry Larry G., Rimbey James N. 1998. The Impact of ownership structure on corporate debt policy: a time series cross sectional analysis.The Financial Review, 33, pp. 85-98.

Nasution, Marihot dan Doddy Setiawan. 2007. Pengaruh Corporate Governance Terhadap Manajemen Laba di Industri Perbankan Indonesia. SNA X Makasar.

Nejad, Hossein Soltani., Sina Zeynali and Seyed Sadegh Alav. 2013. Investigation of Income Smoothing at The Companieslistedon The Stock Exchange By The Using Index Eckel (Case Study: Tehran Stock Exchange). Asian Journal of Management Sciences and Education, 2 (2), pp. 49-62. 
Noronha et. al. 2016. The Impact of Good Corporate Governance on Informative Earnings Management in the Chinese Market. ABACUS, 3(52), hal. 568609.

Noviana, Sindi Retno dan Yuyetta, Etna Nur Afri. 2011.Analisis Faktor-Faktor Yang Mempengaruhi Praktik Perataan Laba (Studi empiris perusahaan manufaktur yang terdaftar di BEI periode 2006 - 2010), Jurnal Akuntansi \&Auditing, 8 (1).

Organization for Economic Cooperarion and Development (OECD). 2004. The OECD Principles of Corporate Governance. Diakses tanggal 1 Juli 2017.

Oktyawati, Dianila dan Agustia Dian. 2014. Pengaruh Profitabilitas, Leverage, Dan Nilai Perusahaan Terhadap Income Smoothing Dan Return Saham Pada Perusahaan Manufaktur Yang Terdaftar Di Bursa Efek Indonesia (BEI). Jurnal Akuntansi \& Auditing, 10 (2). hal. 195-214.

Padachi et. al. 2017. Corporate Governance and Firm's Perfomance of Mauritian Listed Company. International Journal of Financing Management and Reporting Analysis, 1(1), hal. 1-26.

Peranasari, I. A. A. I. dan Dharmadiaksa, I. B. 2014. Perilaku Income Smoothing, Dan Faktor-Faktor Yang Memengaruhinya. E-Jurnal Akuntansi Universitas Udayana, hal.140-153.

Pratama, Dika Fajar. 2012. Pengaruh Profitabilitas, Risiko Keuangan, Nilai Perusahaan, Struktur Kepemilikan Dan Dividend Payout Ratio Terhadap Perataan Laba. Jurnal Akuntansi dan Investasi, 13 (1), hal. 35-43.

Prabayanti, Ni Luh Putu Arik dan Gerianta Wirawan Yasa. 2011. Perataan laba (income smoothing) dan Analisis Fakor-Faktor yang Mempengaruhinya. Journal Universitas Udayana, 6 (1), hal. 1-28.

Prayudi, Dimas. dan Rochmawati Daud. 2013. Pengaruh Profitabilitas, Risiko Keuangan, Nilai Perusahaan dan Struktur Kepemilikan Terhadap Praktik Perataan Laba (Income Smoothing) Pada Perusahaan Manufaktur Yang Terdaftar Di Bursa Efek Indonesia 2008 - 2011. Femasi. 9 (2).

Putra, A. 2014. The Impact of Implementation Good Corporate Governance to Firm Value (Evidence from Indonesian Public Banking Sector). Integrative Business \& Economic Review. 4(1), hal. 95-102.

Putri, I G A Made Asri Dwija. 2012. Analisis Pengaruh Kebijakan Dividen, Budaya Organisasi dan GCG terhadap Manajemen Laba dan Nilai Perusahaan. Buletin Studi Ekonomi, (17), h. 157-171.

Schipper, Khaterine and Vincent L. 2003. Earnings Quality. Acounting Horizons, pp. $97-110$

Scott, W. R, 2006.Financial Accounting Theory. Fourth Toronto: Prentice Hall International Inc. 
Susanto, Sherly., dan Yulius Jogi Christiawan. 2016. Pengaruh Earning Management terhadap Firm Value. Business Accounting Review. 4 (1).

Suranta, Eddy., dan Merdistusi, Pratana Puspita. 2004. Income Smoothing, Tobin's Q, Agency Problems, dan Kinerja Perusahaan. Simposium Nasional Akuntansi.

Wijaya, Putu dan Sunarno. 2015. Analisis Faktor-faktor yang Mempengaruhi Perataan Laba (Studi Kasus Pada Perusahaan Perbankan yang Terdaftar di BEI). Jurnal Ilmiah Manajemen. 3(2), hal. 374-384. 